Mongolian Academy of Sciences
Mongolian Journal of Chemistry
Institute of Chemistry \& Chemical Technology

\title{
Investigation on the possibility of obtaining of motor fuels from bituminous sand by heat treatment
}

\author{
D. Jadamba, B. Ulzii, M. Tuya \\ Institute of Chemistry and Chemical Technology, Mongolian Academy of Science, 13330, Ulan-Bator, \\ Bayanzurkh-51, St.Enkhtaivana, IV. Email: jadamba_dash@yahoo.com
}

Keywords; bituminous sand, thermal treatment, synthetic fuels

\section{Introduction}

$\mathrm{H}$ ave been obtained a oil like liquid product with hydrocarbon type from bituminous sand of Bayan-Erkhet deposits by a heat treatment. Main characteristics and chemical composition of the bitumens isolated by extraction various organic solvents from the bituminuos sand of the Bayan-Erhet deposits are determined. Show that they are similar composition and properties there bitumen asphalt or natural bitumens. The possibility of obtaining of synthetic oil by heat treatment of bitumens is estimated up to $600{ }^{\circ} \mathrm{C}$ in laboratory conditions. Have been determined the possibility of obtaining high-quality oil from the liquid product from the thermal treated bituminous sands of Bayan Erhet by using of $\mathrm{Nb}-\mathrm{Zr}$-aluminosilicate catalyst type ZSM-5, and by varying the temperature of the process. On the basis of this treatment was obtained an additional petroleum products, which are the basic components of motor fuels..

Key words; bituminous sand, thermal treatment, synthetic fuels

\section{Experimental}

The object of the study were samples of bituminous sands of the Bayan-Erkhet deposits. Bituminous sands of Bayan-Erhket deposit is located in the of Tuw aimag Bayanjargalan village, $5 \mathrm{~km}$ from the river
Herlen, $40 \mathrm{~km}$ from the soum centre and 55 $\mathrm{km}$ from the Railway station. The BayanErkhet deposits consists of two oil bearing layers area of $0.025 \mathrm{~km}^{2}$ with a thickness of $0.5-0.6 \mathrm{~m}$ and the lower $-0.4 \mathrm{~km}^{2}$ whit a thickness of $0.1-15.2 \mathrm{~m}$ and has supplies 1913.6 thousand tons of estimated resources.

\section{Results and discussion}

Isolation of bitumen from tar sands, the study of physical and chemical properties.

Results of bituminous sands extraction with various solvents and hot water are shown in Table-1

Table 1. The yields of the bitumens isolated by extraction of various organic solution and hot water from bituminous sand

\begin{tabular}{|c|c|c|l|c|c|c|}
\hline & \multicolumn{5}{|c|}{ Yields of bitumen, mass. \% } \\
\cline { 2 - 7 } & $\begin{array}{c}\text { Deposit } \\
\text { name }\end{array}$ & $\begin{array}{c}\text { Choloro } \\
\text { form } \\
\text { Petrolein } \\
\text { ether } \\
(40-70 \\
\left.{ }^{\circ} \mathrm{C}\right)\end{array}$ & Benzene & $\begin{array}{c}\text { Ethanol } \\
: \\
\text { benzene } \\
(1: 1)\end{array}$ & $\begin{array}{c}\text { Hot } \\
\text { water }\end{array}$ & $\begin{array}{c}\mathrm{NaHCO}_{3} \\
7 \% \\
\text { solution }\end{array}$ \\
\hline $\begin{array}{c}\text { Bayan- } \\
\text { Erhket }\end{array}$ & 14,75 & 11,27 & 0,18 & 0,15 & 7,46 & 9,23 \\
\hline
\end{tabular}

The dates in Table 1 show that the yields of organic matter extracted with chloroform are 14.75 and $20.4 \%$. The extraction of bitumen from tar sands, the best is with choloroform, which was chosen that more polar character than all other applied solvents. 
The content of the bitumen extracted with hot water is $7.5 \mathrm{wt}, \%$ in the Bayan-Erhet deposit. Main technical characteristics of the bituminous sand of Bayan-Erkhet deposit are determined and the results are given in Table 2 .

Table 2. Main technical characteristics of Bituminous sand, mass. $\%$

\begin{tabular}{|l|c|c|}
\hline \multirow{2}{*}{$\begin{array}{c}\text { Technical } \\
\text { charateristics }\end{array}$} & \multicolumn{2}{|c|}{$\begin{array}{c}\text { Deposit of Bayan- } \\
\text { erhket }\end{array}$} \\
\cline { 2 - 3 } & Bitumen & Minerals \\
\hline Moisture, W \% & 0.72 & - \\
\hline $\begin{array}{l}\text { Volatile substance, } \\
\text { V dag }\end{array}$ & 22.52 & 0.79 \\
\hline Ashes, $\mathrm{A}^{\mathrm{a}} \%$ & 73.41 & 99.13 \\
\hline
\end{tabular}

Moisture of extracted bitumens of Bayan-Erkhet $\left(\mathrm{A}^{\mathrm{a}}-0.72 \%\right)$. This moisture is much smaller compared with the moisture of coal, shale and other fossil fuels. This may be due to the hydrophobic property of bitumen.

As a part of natural bitumen tar can be uses as a binder material for asphalt road. The elemental compositions of the studied bitumen extracte from bituminous sands are shown in Table 3.

Table 3. Main technical characteristics of bitumen extracted from bituminous sand

\begin{tabular}{|c|c|c|}
\hline № & Main characteristics: & $\begin{array}{l}\text { Bayan- } \\
\text { Erhket } \\
\text { deposit }\end{array}$ \\
\hline 1 & $\begin{array}{l}\text { Group composition of group organic } \\
\text { compounds, } \% \text { mass. } \\
\text { - asphalt } \\
\text { - resin } \\
\text { - oil } \\
\text { - n-alkanes }\end{array}$ & $\begin{array}{c}6.08 \\
60.19 \\
31.82 \\
1.15\end{array}$ \\
\hline 2 & $\begin{array}{c}\text { The elemental composition, mass\% } \\
\text { C } \\
\mathrm{H} \\
\mathrm{N} \\
\mathrm{S} \\
\mathrm{O} \\
\end{array}$ & $\begin{array}{l}84.11 \\
11.72 \\
1.13 \\
0.29 \\
2.75\end{array}$ \\
\hline 3 & $\begin{array}{l}\text { Specification : } \\
\text { The depth of needle penetration, sSt } \\
\text { Softening temperature, }{ }^{\circ} \mathrm{C} \\
\text { Ductile } 25^{\circ} \mathrm{C}, \mathrm{Cm} \\
\text { Flash point, } \mathrm{C} \\
\text { Density, } \mathrm{kg} / \mathrm{M}^{3} \\
\text { Disrepair } \% \\
\text { Adhesion with marbel } \\
\text { The index of penetration }\end{array}$ & $\begin{array}{c}47,7 \\
36 \\
193 \\
1,03 \\
3,83\end{array}$ \\
\hline
\end{tabular}

Content is four times lower than allowed for materials suitable for the production of bitumen. According to the standard requirement of BND 40/60 technical characteristics such as penetration, softening temperatures and density of bitumen extracted from bituminous sand deposit are suitable for binding material of asphalt road.

The rentgen flourescens analysis results are presented in Figures 1.

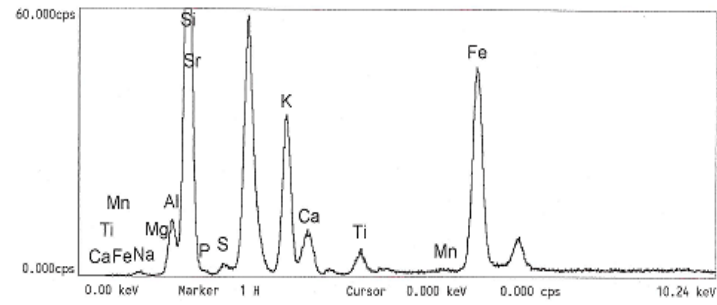

Figure 1 - X-ray spectrum of the mineral part of bituminous sand of the Bayan-Erhet deposits

Table 4. Chemical composition of minerals of bituminous sand

\begin{tabular}{|c|c|c|c|c|c|}
\hline № & $\begin{array}{c}\text { Compositi } \\
\text { on of } \\
\text { minerals }\end{array}$ & $\begin{array}{c}\text { Content, } \\
\% \text { mass. }\end{array}$ & № & $\begin{array}{c}\text { Composition } \\
\text { of minerals }\end{array}$ & $\begin{array}{c}\text { Content, } \\
\% \text { mass. }\end{array}$ \\
\hline 1 & $\mathrm{Na}_{2} \mathrm{O}$ & 1,25 & 7 & $\mathrm{~K}_{2} \mathrm{O}$ & 3,93 \\
\hline 2 & $\mathrm{MgO}$ & 0,19 & 8 & $\mathrm{CaO}$ & 0,28 \\
\hline 3 & $\mathrm{AI}_{2} \mathrm{O}_{3}$ & 9,612 & 9 & $\mathrm{TiO}_{2}$ & 0,11 \\
\hline 4 & $\mathrm{SiO}_{2}$ & 83,85 & 10 & $\mathrm{Mn}_{2} \mathrm{O}_{3}$ & - \\
\hline 5 & $\mathrm{P}_{2} \mathrm{O}_{5}$ & - & 11 & $\mathrm{Fe}_{2} \mathrm{O}_{3}$ & 0,56 \\
\hline 6 & $\mathrm{SiO}_{3}$ & 0,18 & 12 & $\mathrm{SrO}$ & 0,001 \\
\hline
\end{tabular}

The results of X-ray analysis sands show that the composition of the mineral components of the bituminous sands of Bayan- Erhet dominated silica 83.85 and alumimium oxid $9.6 \%$.

\section{The thermal treatment of bituminous sand}

Have been carried out heat treatment of bituminous sands of Bayan Erhet deposits at $600{ }^{\circ} \mathrm{C}$ temperature and determined physicochemical characteristics of the obtained liquid products. The data presented in Table 5.

Table 5. The yield of liquid products obtained by heat treatment of bituminous sand of the Bayan-Erhet deposit

\begin{tabular}{|c|c|c|c|}
\hline \multirow{2}{*}{ Sample } & \multicolumn{3}{|c|}{ The yield of products, \% mass.: } \\
\cline { 2 - 4 } & Liquid & Gas & Solid \\
\hline $\begin{array}{c}\text { Bayan- } \\
\text { Erhket }\end{array}$ & 8.25 & 1.25 & 90.5 \\
\hline
\end{tabular}

As can be seen from Table 5, the yield of liquid product after heat treatment is 8.25 wt.\% for bituminous sands of the BayanErhet deposit. Liquid products were subjected to fractionation on gasoline $\left(\mathrm{NC}-200{ }^{\circ} \mathrm{C}\right.$ ), 
diesel $\left(200-350{ }^{\circ} \mathrm{C}\right)$ and oil $\left(350-450{ }^{\circ} \mathrm{C}\right)$ fraction.The results of atmospheric and vacuum distillation of liquid products of thermal treatment are shown in Table 6.

Table 6. The yield and size distribution of liquid products obtained by heat treatment of bituminous sand of Bayan-Erkhet deposit, mass.\%

\begin{tabular}{|c|c|c|c|c|}
\hline \multirow{2}{*}{ Sample } & \multicolumn{4}{|c|}{ Fractions } \\
\cline { 2 - 5 } & $\begin{array}{c}\mathrm{B}, \mathrm{p}-200 \\
{ }^{\circ} \mathrm{C}\end{array}$ & $\begin{array}{c}200-350 \\
{ }^{\circ} \mathrm{C}\end{array}$ & $\begin{array}{c}350-450 \\
{ }^{\circ} \mathrm{C}\end{array}$ & $\begin{array}{c}\text { yeild }>450 \\
{ }^{\circ} \mathrm{C}\end{array}$ \\
\hline $\begin{array}{c}\text { Bituminous } \\
\text { sand of }\end{array}$ & & & & \\
$\begin{array}{c}\text { Bayan- } \\
\text { Erkhet } \\
\text { deposit }\end{array}$ & 19,5 & 52,2 & 19,86 & 3,98 \\
\hline
\end{tabular}

As seen from the data in Table 6, the output fraction of $\mathrm{b}, \mathrm{p}-200{ }^{\circ} \mathrm{C}$, obtained from the liquid product after pyrolysis of tar sands deposits of the Bayan-Erhet is 19.5, the diesel fraction - 52.2 and oil fractions - $19.86 \mathrm{wt}$. To assess the possibility of synthetic oilsaturated sandstone oil from heat treatment, we carried out a comparison of physical and chemical characteristics of the liquid products derived from sandstones of the Bayan-Erhet, with the fractional composition of commodity gasolines A-80.

Table 7. Technical characteristic of the gasoline fraction $\left(b, p-200{ }^{\circ} \mathrm{C}\right.$ ) of the liquid product after heat treatment

\begin{tabular}{|c|c|c|}
\hline \multirow[b]{2}{*}{ Technical characteristics } & \multicolumn{2}{|c|}{ The amount of study } \\
\hline & $\begin{array}{c}\text { A-80 } \\
\text { gasoline } \\
\text { (GOST- } \\
\text { 2084) }\end{array}$ & $\begin{array}{l}\text { Liquid } \\
\text { products }\end{array}$ \\
\hline $\begin{array}{c}\text { Octan number (no less): } \\
\text {-research methods } \\
\text {-motor methods }\end{array}$ & $\begin{array}{l}>80 \\
>76\end{array}$ & $\begin{array}{l}70,5 \\
67,3\end{array}$ \\
\hline Density , $20^{\circ} \mathrm{C}, \mathrm{g} / \mathrm{cm}^{3}$ & No rated & 0,7659 \\
\hline $\begin{array}{l}\text { Fractional composition, } \\
\text { driven } \\
\text { away at temperature, }{ }^{\circ} \mathrm{C}, \\
\text { distilled: } \\
\qquad \begin{array}{l}10 \text { vol. } \% \\
50 \text { vol. } \% \\
90 \text { vol. } \%\end{array} \\
\text { End boiling point, }{ }^{\circ} \mathrm{C} \text {, not } \\
\text { higher } \\
\text { The residue, } \% \text { volume, max. }\end{array}$ & $\begin{array}{c}>35 \\
<70 \\
<115 \\
<180 \\
205 \\
1,5\end{array}$ & $\begin{array}{c}40 \\
91,7 \\
141,3 \\
205,3 \\
237,6 \\
1,8\end{array}$ \\
\hline $\begin{array}{l}\text { Water-soluble acids and } \\
\text { alkalis }\end{array}$ & \multicolumn{2}{|c|}{ No } \\
\hline Test on copper plate stand & \multicolumn{2}{|c|}{ Stand up } \\
\hline The color & \multicolumn{2}{|c|}{ Yellow } \\
\hline $\begin{array}{l}\text { Water content (volume. } \\
\% \text { ), }\end{array}$ & \multicolumn{2}{|c|}{ No } \\
\hline $\begin{array}{l}\text { Content of mechanical } \\
\text { impurities, } \% \text { wt. }\end{array}$ & \multicolumn{2}{|c|}{ No } \\
\hline
\end{tabular}

The eight fraction (b.p $-200{ }^{\circ} \mathrm{C}$ ) of the liquid products after heat treatment of bituminous sand can be a useful raw material for preparation of commercial gasoline in the refining equipments for oil by using catalityc process.

The determined characteristics of a diesel fraction $\left(200-350{ }^{\circ} \mathrm{C}\right)$ of bituminous sand of Bayan-Erhet deposit compared with commercial diesel fuel and demonstrated in Table 8.

Table 8. Characteristics of the diesel fraction (200 $350^{\circ} \mathrm{C}$ ) of liquid products of thermal processing of bituminous sand.

\begin{tabular}{|c|c|c|}
\hline \multirow[b]{2}{*}{ Characteristics } & \multicolumn{2}{|c|}{ Values } \\
\hline & $\begin{array}{c}\text { Flight of } \\
\text { diesel fuel, } \\
\text { GOST-305- } \\
82\end{array}$ & $\begin{array}{l}\text { "Bayan- } \\
\text { Erkhet" } \\
\text { fraction of } \\
\text { diesel }\end{array}$ \\
\hline Cetan number, (no less) & 45 & 42 \\
\hline $\begin{array}{l}\text { Kinematic viscosity at } \\
20^{\circ} \mathrm{C}, \mathrm{mm} 2 / \mathrm{s}(\mathrm{cSt})\end{array}$ & $3.0-6.0$ & 6.87 \\
\hline $\begin{array}{l}\text { Kinematic viscosity at } \\
50^{\circ} \mathrm{C}, \mathrm{mm} 2 / \mathrm{s}(\mathrm{cSt})\end{array}$ & $1.3-2.4$ & 3.23 \\
\hline $\begin{array}{l}\text { Flash point in a closed } \\
\text { crucible, }{ }^{\circ} \mathrm{C} \text {, below: }\end{array}$ & 40 & 62 \\
\hline Pour point, ${ }^{\circ} \mathrm{C}, \max$ & -10 & -1.5 \\
\hline Density $20^{\circ} \mathrm{C}, \mathrm{g} / \mathrm{cm}^{3}$ & 0,860 & 0,862 \\
\hline \multicolumn{3}{|c|}{ Fractional composition, ${ }^{\circ} \mathrm{C}$ : } \\
\hline $\begin{array}{l}50 \% \text { vol. distils at a } \\
\text { temperature, }{ }^{\circ} \mathrm{C} \text {, max }\end{array}$ & 280 & 268 \\
\hline $\begin{array}{l}96 \% \text { vol. distils at a } \\
\text { temperature, }{ }^{\circ} \mathrm{C}, \max \end{array}$ & $340-360$ & 350,1 \\
\hline $\begin{array}{c}\text { Content of sulfur, } \\
\text { mass. } \%\end{array}$ & $0,2-0,5$ & 0,33 \\
\hline
\end{tabular}

In the one hand the value of viscosity, density at $20^{\circ} \mathrm{C}$ and the sulfur content of diesel fractions are close to the standard indicators of summer diesel fuel.in the other hand such as pour point and cetane number are different then the characteristic of commercial diesel fuel.

Thus, the results of technical performance of various fractions of liquid products of thermal treatment of bituminous sand of the BayanErhet deposits and indicate the possibility of their successful preperation the combined fuel-oil version, which includes the processes of catalytic refining, hydrotreating, and dewaxing.

\section{Catalytic refining synthetic crude oil obtained from bituminous sandstone field Bayan- Erhet using zeolite catalysts.}


Table-9 presents the most important products, yield, and octane number of gasoline obtained by using of $0.5 \% \mathrm{Nb}-2.5 \%$ $\mathrm{Zr} / \mathrm{AS}$ catalyst at different temperatures $\left(\mathrm{W}=2 \mathrm{~h}^{-1}, \mathrm{P}=0.1 \mathrm{MPa}\right)$ The results of feedstock are shown in Table-9.

Table 9. Content of product, yield, and octane number of gasoline obtained over $0.5 \% \mathrm{Nb}-2.5 \% \mathrm{Zr} / \mathrm{AS}$ catalyst at different temperatures

$\left(\mathrm{W}=2 \mathrm{~h}^{-1}, \mathrm{P}=0.1 \mathrm{MPa}\right)$

\begin{tabular}{|c|c|c|c|c|c|c|c|}
\hline \multirow{2}{*}{$\begin{array}{c}\text { Products, } \\
\text { wt.\% }\end{array}$} & \multicolumn{7}{|c|}{ Temperatures, ${ }^{\circ} \mathrm{C}$} \\
\cline { 2 - 8 } & 320 & 340 & 360 & 380 & 400 & 420 & 440 \\
\hline N-alkanes & 20.4 & 19.2 & 17.7 & 9.2 & 7.7 & 6.1 & 4.2 \\
\hline Iso-alkanes & 22.3 & 22.5 & 22.9 & 19.4 & 20.8 & 19.2 & 16.5 \\
\hline Alkenes & 18.0 & 15.6 & 14.9 & 11.7 & 11.1 & 5.3 & 1.5 \\
\hline Naphthenes & 19.1 & 20.4 & 20.6 & 17.3 & 13.2 & 15.6 & 11.9 \\
\hline $\begin{array}{c}\text { Aromatic } \\
\text { hydrocarbon } \\
\text { s }\end{array}$ & 20.3 & 22.4 & 24.0 & 42.4 & 47.3 & 53.9 & 66.0 \\
\hline Benzene & 1.1 & 1.1 & 1.1 & 1.5 & 2.1 & 3.2 & 4.3 \\
\hline $\begin{array}{c}\text { Yield of } \\
\text { gasoline, } \%\end{array}$ & 99.8 & 98.0 & 97.5 & 94.0 & 87.0 & 77.0 & 54.0 \\
\hline $\begin{array}{c}\text { Octane } \\
\text { number }\end{array}$ & 68 & 69 & 70 & 85 & 88 & 92 & 102 \\
\hline $\begin{array}{c}\text { Index of } \\
\text { refraction, } \\
\mathrm{n}_{\mathrm{D}}{ }^{20}\end{array}$ & 1.4324 & 1.4332 & 1.4338 & 1.4476 & 1.4592 & 1.4616 & 1.4682 \\
\hline
\end{tabular}

It is evident from the data shown in the Table-9, that gasolines with high octane number are produced over the investigated catalyst at higher $380{ }^{\circ} \mathrm{C}$ and at $440{ }^{\circ} \mathrm{C}$. An increase in reaction of temperatures results in an increase in the concentration of aromatic hydrocarbons and a decrease in the content of normal alkanes, alkenes and cycloalkanes in the gasoline obtained over the catalyst studied.

Component of alkene's hydrocarbons $(19.0 \%)$ of gasoline fraction from bituminous sand show that with the increase of temperature there was an increase in the degree of conversion of aromatics hydrocarbons. A gasoline fraction with yield 94-77\% and with octane number 85-92 was obtained in the presence of zeolite catalyst from bituminous sand of temperatures 380$420{ }^{\circ} \mathrm{C}$. The yields of gas phase increased in the temperature of $440{ }^{0} \mathrm{C}$, because of intensification of cracking process of bituminous sand. Table 10. Characteristics of diesel fraction (180-360 ${ }^{\circ}$ C) after termolysis and catalytic processing of bituminous sand have been determined and presented in Table 10.
Table 10. Characteristics of diesel fraction (180-360 ${ }^{\circ}$

C) after termolysis and catalytic processing of bituminous sand.

\begin{tabular}{|l|c|c|}
\hline \multicolumn{1}{|c|}{ Characterization } & $\begin{array}{c}\text { Diesel } \\
\text { fraction of } \\
\text { feedstock }\end{array}$ & $\begin{array}{c}\text { Diesel } \\
\text { fraction after } \\
\text { of conversion }\end{array}$ \\
\hline Density $20^{\circ} \mathrm{C}, \mathrm{g} / \mathrm{sm}^{3}$ & 0,860 & 0,872 \\
Index of refraction, $\mathrm{n}_{\mathrm{D}}{ }^{20}$ & 1,4732 & 1,4820 \\
Viscosity $20^{\circ} \mathrm{C}, \mathrm{MM}^{2} / \mathrm{c}(\mathrm{cCr})$ & 4,3 & 3,9 \\
Viscosity $50^{\circ} \mathrm{C}^{\mathrm{MM}}{ }^{2} \mathrm{c}(\mathrm{cCr})$ & 2,5 & 2,3 \\
Cloud tempetrature, ${ }^{\circ} \mathrm{C}$, & -8 & -21 \\
Pour point ${ }^{\circ} \mathrm{C}$, & -20 & -37 \\
Index of cetane & 42 & 38 \\
Yield of products, \% & - & 90 \\
\hline
\end{tabular}

The processing of bituminous sand such thermolysis and catalytic cracking lead to improvement of its low temperature performance, reduce viscosity, increase the density and refractive index (Table 6) that due to with cracking of normal paraffins and the formation of aromatic compounds.

Gasoline fraction (b.p $-180^{\circ} \mathrm{C}$ ), isolated from the diesel fraction catalyte processing of termolysis of bituminous sand contained 7.6\% alkanes, isoparaffins $20.3 \%, \quad 13.9 \%$ naphthenes, 9.1\% alkenes, 49, $1 \%$ aromatic hydrocarbons, and had octane number 88 points.

\section{Conclusions}

- Bituminous sand of Bayan-Erhet deposit belongs to natural bitumen with high content of organic matters, especially resin-asphalt components. On a data set about composition and properties the type of bitumens is established: bitumen from bituminous sands of a deposit the Bayan-Erhet concerns to asphalt, natural bitumens.

- Have been estimated the possibility of obtaining of synthetic oil from the bituminous sand of Bayan-Erkhet deposit by heat treatment at $600{ }^{\circ} \mathrm{C}$ in the laboratory conditions and the obtained liquid products were similar with the appropriating fractions of oil.

- Established the possibility of obtaining high-quality oil from the liquid product after thermal treatment of bituminous sand Bayan Erhet deposit with $\mathrm{Nb}-\mathrm{Zr}$-aluminosilicate catalyst (structure type ZSM-5) obtained an additional quantity of 
petroleum products, which are the basic components of motor fuels.

\section{References}

1.С.Пател. Канадские битуминозные пески: благоприятные возможности, технологии и проблемы //Нефтегазовые технологии. 2007. №6. с. 87-93.

2.Х. Болормаа, Ө. Энхтөгс, Н. Чимид. Отчёт об исследовании горючих ископаемых из бассейнов центральной части Монголии. Уланбатор. 1997. с. 107-110.

3.T. Арвижих, С. Очирбат, Д. Дашзэвэг, Ч. Лхагважав. Исследование дорожностроительных материалов. Улан-Батор.2005, c.331-397.
4.Б.М. Рыбак. Анализ нефти и нефтепродуктов. Гостоптехизда, 1962. c. 888 .

5.А.И. Богомолова, М.Б. Темянко, Л.И. Хотынцева. Современные методы анализа нефтей. -Л. - Недра. - 1984. c. 432 .

6.Л.Мөнхтогоо, Б.Чулуун, Ж.Дашдондов. Отчёт геолого-разведочной экспедиции об исследовании бассейна Баян-Эрхэт, Монголия. ТГЭ, Улан-Батор, 1986.

7.А.С. Колбанов, В.В. Михайлов. Дорожные битумы. - М. - Транспорт. 1973.-c.261. 